\title{
WYKAZ PRAC \\ Profesora doktora habilitowanego StanisŁawa Misztala
}

1. Plan regionalny Częstochowskiego Okręgu Przemystowego, Biuro Planów Regionalnych przy PKPG (wydanie powielone), Warszawa 1955, ss. 270 (współautorstwo).

2. Przykłady jakich wiele. Po co podzielono Żyrardowskie Zakłady Przemystu Włókienniczego (głos w dyskusji), [w:] Nasza ankieta - jak usprawnić zarzqdzanie gospodarkq narodowa, Trybuna Ludu, 1956, nr 157, s. 3.

3. Stare mury w Nowym Mieście, Trybuna Ludu, 1956, nr 187, s. 4.

4. Ekspertyza do planu regionalnego Okręu Warszawskiego, BPR przy PKPG (wydanie powielone), Warszawa 1956, ss. 200 (współautorstwo).

5. Za rogatkami stolicy, Życie Gospodarcze, 1956, nr 24, s. 12.

6. Badania w zakresie przemystu w planie regionalnym województwa, Inwestycje i Budownictwo, 1958, nr 9, s. 33-39 (wspólnie z S. Gajowskim).

7. Problem zaopatrzenia Warszawy $i$ woj. warszawskiego $w$ podstawowe materiaty budowlane, Inwestycje i Budownictwo, 1958, nr 10, s. 30-34.

8. Przemiany w strukturze i rozmieszczeniu przemystu na terenie woj. warszawskiego i m. Warszawy, Przegląd Geograficzny, 1958, t. 30, z. 4, s. 587-618.

9. Wstepna koncepcja rozwoju i zagospodarowania woj. warszawskiego w latach 1961-1975 (wydanie powielone), Prezydium WRN w Warszawie, Warszawa 1958, ss. 190.

10. Rozwój energetyki i przemysłu paliw w regionie warszawskim, WKPG, Warszawa 1958, ss. 65 (wydanie powielone).

11. Perspektywy rozwoju przemystu w woj. warszawskim do 1975 r., Inwestycje i Budownictwo, 1959, nr 6, s. 8-14 (wspólnie z S. Gajowskim).

12. Problem kooperacji przemyslu drobnego z przemystem kluczowym na przykladzie niektórych zakładów Okręu Warszawskiego, Zeszyty Komisji Planowania przy RM, 1959, ss. 20 (wspólnie z J. Gronostajskim).

13. Województwo warszawskie, [w:] Wstępne koncepcje rozwoju i zagospodarowania województw w latach 1961-1975, I Region Stoteczny i Pótnocno-Wschodni, Komisja Planowania przy RM, Warszawa 1959, s. W1-W151 (współautorstwo).

14. Warunki potencjalne dla lokalizacji przemystu $w$ woj. warszawskim (mapa-załącznik w skali 1:300 000), [w:] Wstęne koncepcje rozwoju i zagospodarowania województw w latach 19611975, I Region Stołeczny i Pólnocno-Wschodni, Komisja Planowania przy RM, Warszawa 1959 (wspólnie z S. Gajowskim).

15. Zatrudnienie $w$ przemyśle i rzemiośle w powiatach województwa warszawskiego $w 1956 r$. (mapa-załącznik w skali 1:300 000), [w:] Wstęne koncepcje rozwoju i zagospodarowania województw w latach 1961-1975, I Region Stoleczny i Pólnocno-Wschodni, Komisja Planowania przy RM, Warszawa 1959 (wspólnie z S. Gajowskim).

16. Rozmieszczenie przemystu i rzemiosta $w$ stanie istniejacym (1956) $i$ w perspektywie (1975), (mapa-załącznik w skali 1:300 000, [w:] Wstęne koncepcje rozwoju i zagospodarowania województw w latach 1961-1975, I Region Stoteczny i Pótnocno-Wschodni, Komisja Planowania przy RM, Warszawa 1959 (wspólnie z S. Gajowskiem).

17. Atlas Przemystu Warszawskiego Okręgu Przemystowego (wydanie fotograficzne i powielone w małym formacie A4), KPZK PAN, Warszawa 1961, 20 s. + 60 map. 
18. Atlas Przemystu Warszawskiego Okręgu Przemystowego (wydanie fotograficzne i powielone w dużym formacie A3), KPZK PAN, Warszawa 1961, 20 s. + 60 map.

19. Przemyst mineralny w woj. białostockim, Dokumentacja Geograficzna, 1961, z. 3, s. 1-88.

20. Warszawski Okręg Przemystowy - studium rozwoju i lokalizacji przemyshu (autoreferat rozprawy doktorskiej), IG PAN (wydanie powielone), Warszawa 1961, ss. 9.

21. Warszawski Okręg Przemysłowy - studium rozwoju i lokalizacji przemystu, Studia KPZK PAN, t. III, Warszawa 1962, ss. $234+41$ map + 13 tabel.

22. Zagadnienia rozwoju przemystu mineralnego w woj. bialostockim, [w:] Podstawy rozwoju woj. białostockiego (wydanie powielone), Prezydium WRN w Białymstoku, Białystok 1962, cz. II, s. $190-210$.

23. Bibliographie der Industriegeographie der Schweiz, Institut für Orts - Regional und Landesplanung - Eidgenössische Technische Hochschule, Zürich 1963, ss. 43.

24. Landesplanung in Polen, Plan - Schweizerische Zeitschrift für Landes - Regional und Ortsplanung, Zürich, nr 11/12, s. 206-213.

25. Wacław Nałkowski, W pięćdziesiata rocznice zgonu (1911-1961), Warszawa 1962, recenzja, Geographica Helvetica, 1963, nr 2.

26. Guide of the trip to Ptock (wydanie powielone), IG PAN, 1963, 12 s. + 1 tabela (wspólnie z P. Eberhardtem).

27. Geografia w Szwajcarii, Przegląd Geograficzny, 1964, z. 2, s. 333-342.

28. Proces uprzemysłowienia woj. warszawskiego w XX-leciu Polski Ludowej (wydanie powielone), Rada Naukowo-Ekonomiczna przy Prezydium WRN w Warszawie, Warszawa, 1964, ss. 21.

29. Sprawozdanie z dziatalności Instytutu Geografii PAN w 1963 r., Przegląd Geograficzny, 1964, z. 4, s. 804-810 (wspólnie z M. Jeżewska).

30. Historyczne formowanie się Warszawskiego Okręgu Przemystowego (8 map), [w:] Plan Regionalny Regionu Warszawskiego (m.st. Warszawy $i$ woj. warszawskiego 1960-1980), Wojewódzka Pracownia Planów Regionalnych, Warszawa 1964, cz. II, rozdz. III, s. 2-3.

31. Some problems of formation and development of the Warsaw Industrial District, Geographia Polonica, 1965, 7, s. 57-67.

32. Sprawozdanie z dziatalności Instytutu Geografii PAN w 1964 r., Przegląd Geograficzny, 1965, z. 4, s. 738-743 (wspólnie z M. Jeżewską).

33. Głos $w$ dyskusji na temat rozwoju przemystu $w$ regionie warszawskim, [w:] Problemy rozwoju Regionu Warszawskiego, Materiały z Konferencji Naukowej PTE (12-14 VI 1966 r.), Warszawa 1966, s. 135-138.

34. Gtos $w$ dyskusji na temat statystyki regionalnej, [w:] Statystyka regionalna-aktualny stan i problemy rozwoju, Materiały z Konferencji GUS (26-27 VI 1967 r.), Warszawa 1967, s. 303-309.

35. Proces uprzemystowienia woj. warszawskiego w XX-leciu Polski Ludowej, Rocznik Mazowiecki, 1967, I, Warszawa, s. 136-149.

36. Przemyst, [w:] S. Leszczycki i L. Kosiński (red.), Zarys geografii ekonomicznej Polski, Warszawa 1967, s. 115-145.

37. Sprawozdanie z dziatalności Komitetu Nauk Geograficznych PAN w 1966 r., Przegląd Geograficzny, 1967, z. 3, s. 645-646.

38. Przemyst, [w:] J. Kostrowicki (red.), Województwo białostockie. Monografia geograficzno-gospodarcza, Wydawnictwo Lubelskie, Lublin 1967, s. 399-496.

39. Sprawozdanie z dziatalności Komitetu Nauk Geograficznych PAN w 1967 r., Przegląd Geograficzny, 1968, z. 3, s. 689-690.

40. Warszawski Okręg Przemysłowy, [w:] Przewodnik wycieczek X Ogólnopolskiego Zjazdu Geograficznego, 10-22 IX 1968 r., PTG, Warszawa 1968, s. 76-86.

41. Cegielnie i kaflarnie na tle bazy surowcowej, [w:] Atlas województwa bialostockiego, IGiPZ PAN, Warszawa, 1968, s. 46 (mapa w skali 1:300 000).

42. Rozwój i rozmieszczenie przemystu Warszawy międzywojennej, [w:] Studia Warszawskie, Warszawa II Rzeczypospolitej 1918-1939, PWN, t. II, Warszawa 1969, s. 7-47, 3 mapy-wkładki. 
43. Recenzja pracy M.H. Drozdowskiego „Klasa robotnicza Warszawy 1918-1939”, Kwartalnik Historyczny, 1969, z. II, s. 502-506.

44. Rozmieszczenie ważniejszych ośrodków przemystowych Polski w 1946 i 1969 r., Poznaj Świat, 1969, 7, s. 23 (wspólnie z H. Simbierowicz).

45. Warszawski Okręg Przemysłowy, [w:] Wielka Encyklopedia Powszechna, t. XII, PWN, Warszawa 1969, s. 132.

46. Sprawozdanie z działalności Komitetu Nauk Geograficznych PAN za rok 1968, Przegląd Geograficzny, 1969, z. 3, s. 568-569.

47. Przemiany $w$ strukturze przestrzennej przemystu na ziemiach polskich $w$ latach 1860-1965, Studia KPZK, t. XXI, Warszawa 1970, ss. $220+14$ map.

48. Przemyst, [w:] Warszawa-rozwój miasta w 25-leciu PRL, PWN, Warszawa 1970, s. 106-146.

49. Przemyst chemiczny na obszarze Polski w latach 1860-1945, [w:] Uprzemystowienie ziem polskich w XIX i XX wieku, Ossolineum, Wrocław-Warszawa-Kraków 1970, s. 359-385.

50. Zmiany w rozmieszczeniu przemystu na obszarze Polski w latach 1860-1960, [w:] Uprzemystowienie ziem polskich w XIX i XX wieku, Ossolineum, Wrocław-Warszawa-Kraków 1970, s. 647-654, 8 map w skali 1:4 0000000 .

51. Changes in the distribution of industry on the teritory of Poland in the years 1860-1965, [w:] Studia Historiae Oeconomicae, t. 5, Poznań, 1970, s. 231-241, 4 mapy w skali 1:3 000000.

52. Rozwój przemystu Pragi w 25-leciu PRL, [w:] Dzieje Pragi, PWN, Warszawa 1970, s. 299-313.

53. Przemyst, [w:] S. Leszczycki (red.), Zarys geografii ekonomicznej Polski, PWN, Warszawa 1971, wydanie II zmienione, s. 116-153.

54. Węzlowe problemy gospodarcze Warszawy w latach 1918-1939, [w:] Studia Warszawskie, Warszawa II Rzeczypospolitej 1918-1939, t. VII, PWN, Warszawa, 1971, z. 3, s. 335-350.

55. Zum Wiederaufbau der polnische Haupstadt Warschau, Geographische Berichte, Potsdam 1971, nr 61, s. 271-283.

56. Przemyst, [w:] Warszawskie - rozwój województwa w Polsce Ludowej, PWN, Warszawa 1972, s. $138-176$.

57. Przemyst i rzemiosto, [w:] S. Berezowski (red.), Powiat lipski-geograficzno-ekonomiczne problemy wspótczesne, Radomskie Towarzystwo Naukowe, Radom-Lódź 1972, s. 148-170.

58. Die Entwicklung der polnischen Ballungsgebiete, Petermanns Geograhischen Mitteiilugen, Gotha-Leipzig 1972, nr 116, z. I, s. 22-24.

59. Studies on the spatial structure of industry, Geographia Polonica, 1972, $\mathrm{nr} 22$, s. 113-121.

60. Studies of long-term changes in the spatial structure of industry in 1860-1960 - on the example of Poland, [w:] International Geography 1972, IGU, Montreal, 1972, s. 572-573.

61. Warszawski Okręg Przemystowy, [w:] Historia Polski, t. III, cz. II, PWN, Warszawa 1972, s. 48, mapa w skali 1:750 000 .

62. Ważniejsze ośrodki przemysłowe w 1970 r., [w:] S. Leszczycki i T. Lijewski (red.), Geografia przemystu Polski, PWN, Warszawa 1972, załącznik - mapa w skali 1:2 500000.

63. Rozwój przemystu na Mokotowie, [w:] Dzieje Mokotowa, PWN, Warszawa 1972, s. 249-270.

64. Industrializacja ziem polskich $w$ okresie kapitalizmu, [w:] S. Leszczycki i T. Lijewski (red.), Geografia przemystu Polski, PWN, Warszawa 1972, s. 118-142.

65. Charakterystyka okręgów przemystowych, [w:] S. Leszczycki i T. Lijewski (red.), Geografia przemystu Polski, PWN, Warszawa 1972, s. 327-366.

66. Rozwój przemystu na Ochocie, [w:] Dzieje Ochoty, PWN, Warszawa 1972, s. 209-227.

67. Przemyst Warszawy w okresie okupacji niemieckiej 1939-1945, [w:] Warszawa lat wojny i okupacji. Studia Warszawskie I, t. XVII, Warszawa 1973, z. 3, s. 305-316.

68. Głos w dyskusji na sesji naukowej na temat: Społeczeństwo i ruch oporu w Warszawie lat wojny i okupacji 1939-1944, [w:] Warszawa lat wojny i okupacji. Studia Warszawskie I, t. XVII, PWN, Warszawa 1973, s. 417-418.

69. Uwagi o mapach rozmieszczenia przemystu w Atlasie Historycznym Polski, Geografia w Szkole, 1973, 5, s. 290-293. 
70. Przemyst Woli w latach 1939-1972, [w:] Dzieje Woli, PWN, Warszawa 1974, s. 487-505.

71. Industrializacja ziem polskich $w$ okresie kapitalizmu, [w:] S. Leszczycki i T. Lijewski (red.), Geografia przemystu Polski, II wyd., PWN, Warszawa 1974, s.120-144.

72. Charakterystyka okręgów przemystowych, [w:] Geografia przemysłu Polski, II wyd., PWN, Warszawa 1974, s. 322-360.

73. Ważniejsze ośrodki przemysłowe w 1970 r., [w:] Geografia przemystu Polski, II wyd., PWN, Warszawa 1974, załącznik mapa 1:2,5 mlm.

74. Przemyst (mapa 1:50 000), [w:] Atlas Warszawy, Urząd Miasta Stołecznego Warszawy, Warszawa 1975, plansza nr 15.

75. Objaśnienia do Atlasu, [w:] Atlas Przemystu Polski, IGiPZ PAN, Warszawa 1975, s. VII-X (wspólnie z T. Lijewskim).

76. Zatrudnienie w przemyśle 1860, mapa 1:2 mln, [w:] Atlas Przemystu Polski, plansza nr 2.

77. Zatrudnienie w przemyśle 1910, mapa 1:2 mln, [w:] Atlas Przemystu Polski, plansza nr 3.

78. Zatrudnienie w przemyśle 1938, mapa 1:2 mln, [w:] Atlas Przemystu Polski, plansza nr 4.

79. Zatrudnienie w przemyśle 1946, mapa 1:2 mln, [w:] Atlas Przemyshu Polski, plansza nr 5.

80. Zatrudnienie w przemyśle 1965, mapa 1:2 mln, [w:] Atlas Przemystu Polski, plansza nr 6.

81. Struktura wielkości zakładów przemysłowych 1946, mapa 1:2 mln, [w:] Atlas Przemystu Polski, plansza $\mathrm{nr} 7$.

82. Struktura wielkości zakładów przemystowych 1965, mapa 1:2 mln, [w:] Atlas Przemystu Polski, plansza $\mathrm{nr} 8$.

83. Struktura zatrudnienia w przemyśle wg ptci 1965, mapa 1:2 mln, [w:] Atlas Przemystu Polski, plansza nr 9.

84. Kobiety zatrudnione $w$ przemyśle 1965, mapa 1:2 mln, [w:] Atlas Przemystu Polski, plansza nr 10.

85. Wartość produkcji globalnej przemystu 1965, mapa 1:2 mln, [w:] Atlas Przemystu Polski, plansza nr 12.

86. Wartość brutto środków trwatych 1965, mapa 1:2 mln, [w:] Atlas Przemysłu Polski, plansza nr 14.

87. Moc zainstalowana urzqdzeń napędowych 1965, mapa 1: 1:2 mln, [w:] Atlas Przemystu Polski, plansza nr 15.

88. Powierzchnia terenów przemystowych 1965, mapa 1: 1:2 mln, [w:] Atlas Przemystu Polski, plansza nr 18.

89. Uprzemysłowienie powiatów, I, 4 mapy 1:4 mln, [w:] Atlas Przemysłu Polski, plansza nr 20.

90. Uprzemysłowienie powiatów II, 4 mapy 1:4 mln, [w:] Atlas Przemystu Polski, plansza nr 21.

91. Okregi przemystowe 1965, mapa 1:2 mln, [w:] Atlas Przemystu Polski, plansza nr 23.

92. Potencjat produkcyjny okręgów przemystowych 1965, mapa 1:2 mln, [w:] Atlas Przemystu Polski, plansza nr 24.

93. Struktura gałęziowa zatrudnienia w przemyśle okręgów przemysłowych 1965, mapa 1:2 mln, [w:] Atlas Przemystu Polski, plansza nr 25.

94. Ośrodki przemystu paliwowo-energetycznego 1946, mapa 1:2 mln, [w:] Atlas Przemystu Polski, plansza nr 29.

95. Ośrodki przemysłu paliwowo-energetycznego 1965, mapa 1:2 mln, [w:] Atlas Przemystu Polski, plansza $\mathrm{nr} 30$.

96. Elektrownie 1946, mapa 1:2 mln, [w:] Atlas Przemystu Polski, plansza nr 31.

97. Ośrodki przemystu metalurgicznego i maszynowo-metalowego 1946 (wspólnie z M. Horoch), mapa 1:2 mln, [w:] Atlas Przemystu Polski, plansza nr 34.

98. Ośrodki przemystu metalurgicznego i maszynowo-metalowego 1965, mapa 1:2 mln, [w:] Atlas Przemystu Polski, plansza nr 35.

99. Zaktady przemystu metalurgicznego 1970, 2 mapy 1:4 mln i 2 mapy 1:650 tys., [w:] Atlas Przemystu Polski, plansza nr 36. 
100. Ośrodki przemystu chemicznego 1946, mapa 1:2 mln, [w:] Atlas Przemystu Polski, plansza nr 42.

101. Ośrodki przemystu chemicznego 1965, mapa 1:2 mln, [w:] Atlas Przemystu Polski, plansza nr 43.

102. Ośrodki przemystu mineralnego 1946, mapa 1:2 mln, [w:] Atlas Przemystu Polski, plansza nr 46.

103. Kamieniołomy 1970, mapa 1:2 mln, [w:] Atlas Przemystu Polski, plansza nr 48.

104. Kopalnie żwirów i piasków 1970, mapa 1:2 mln, [w:] Atlas Przemysłu Polski, plansza nr 49.

105. Kopalnie surowców ilastych 1971, mapa 1:2 mln, [w:] Atlas Przemystu Polski, plansza nr 50.

106. Ośrodki przemystu włókienniczego 1946, mapa 1:2 000 000, [w:] Atlas Przemysłu Polski, plansza $\mathrm{nr} 63$.

107. Ośrodki przemysłu włókienniczego 1965, mapa 1:2 mln, [w:] Atlas Przemystu Polski, plansza $\mathrm{nr} 64$.

108. Ośrodki przemystu odzieżowego i skórzano-obuwniczego 1946, mapa 1:2 mln, [w:] Atlas Przemystu Polski, plansza nr 69.

109. Ośrodki przemystu odzieżowego i skórzano-obuwniczego 1965, mapa 1:2 mln, [w:] Atlas Przemystu Polski, plansza nr 70.

110. Ośrodki przemystu spożywczego 1946, mapa 1:2 mln, [w:] Atlas Przemystu Polski, plansza nr 73.

111. Ośrodki przemystu spożywczego 1965, mapa 1:2 mln [w:] Atlas Przemystu Polski, plansza nr 74.

112. Przetwórnie owoców i warzyw 1970 (wspólnie z J. Tobiaszem), mapa 1:2 mln, [w:] Atlas Przemystu Polski, plansza nr 81.

113. Prywatne rzemiosto przemystowe 1965, mapa 1:2 mln, [w:] Atlas Przemystu Polski, plansza nr 85 .

114. A. Wrzosek, Gtówne Okręgi Przemystowe Polski, Warszawa, 1972, PZWS, Przegląd Geograficzny, 1975, t. XLVII, z. 1, s. 186-188 (recenzja).

115. Budapest an industrial-geographical approach, Budapest, 1972, Akademiai Kiado, ss. 168, Przegląd Geograficzny, 1975, 47, 2, s. 430-432 (recenzja).

116. Przemyst (hasło), [w:] Encyklopedia Warszawy, PWN, Warszawa 1975, s. 539-541.

117. Warszawski Okręg Przemysłowy, (hasło), [w:] Encyklopedia Warszawy, PWN, Warszawa 1975, s. 729.

118. Zachodnia Dzielnica Przemystowa (hasło), [w:] Encyklopedia Warszawy, PWN, Warszawa 1975, s. 773-774.

119. Przemyst Śródmieścia Warszawy (1864-1973), [w:] Dzieje Śródmieścia, PWN, Warszawa 1975, s. 623-640.

120. Rozwój ważniejszych ośrodków przemystowych w latach 1910-1960, 4 mapy 1:4 mln, [w:] Narodowy Atlas Polski, IGiPZ PAN, Warszawa 1974-1978, plansza nr 92.

121. Ośrodki przemystowe w 1970 r., mapa 1:2 mln, [w:] Narodowy Atlas Polski, IGiPZ PAN, Warszawa 1974-1978, plansza $\mathrm{nr} 94$.

122. Przemysł elektroenergetyczny, mapa 1:2 mln, [w:] Narodowy Atlas Polski, IGiPZ PAN, Warszawa 1974-1978, plansza $\mathrm{nr} 95$.

123. Przemyst metalurgiczny, mapa 1:2 mln, [w:] Narodowy Atlas Polski, IGiPZ PAN, Warszawa 1974-1978, plansza nr 97.

124. Okręgi przemystowe, mapa 1:2 mln, [w:] Narodowy Atlas Polski, IGiPZ PAN, Warszawa 19741978, plansza nr 105.

125. The spatial structure of polish industry in 1970, [w:] The Organisation of Spatial Industrial Systems, IGU Working Group on Industrial Geography, Novosibirsk 1976, s. 187-189.

126. Geografia dell'acciaio (a cura di Ernesto Massi), Milano, volume primo 1973, ss. 304, volume secondo 1975, ss. 576, Przegląd Geograficzny, 1977, 49, 2, s. 373-373 (recenzja). 
127. Aktuelle Tendenzen, der Raumplanung in Polen, [w:] Der ländliche Raum - eine Aufgabe der Raumplanung, Festschrift für Theo Weidmann und Ernst Winkler, Schriftenreihe zur Orts-Regional und Landesplanung, ORL Institut ETH Zürich, 1977, 28, s. 175-180.

128. Głos $w$ dyskusji na temat problemów aglomeracji warszawskiej, Kronika Warszawy, 1977, 2, s. $11-12$.

129. Głos w dyskusji na temat strategii rozwoju regionów, [w:] Region Białostocki-studia ekonomiczno-społeczne, PTE i OBN, Białystok 1977, t. V, s. 301-303.

130. Branże wiodace stolecznego przemystu w latach 1945-1976, [w:] Wielkie zaktady przemystowe Warszawy, PWN, Warszawa 1978, s. 107-144.

131. Ważniejsze zakłady przemystowe Warszawy w 1913 r., [w:] Wielkie zaktady przemystowe Warszawy, PWN, Warszawa 1978, załącznik 1 - mapa 1:100 000.

132. Ważniejsze zaktady przemystowe Warszawy w 1938 r., [w:] Wielkie zaktady przemystowe Warszawy, PWN, Warszawa 1978, załącznik 2 - mapa 1:100 tys.

133. Ważniejsze zaktady przemystowe Warszawy w 1975 r., [w:] Wielkie zaklady przemystowe Warszawy, PWN, Warszawa 1978, załącznik 3 - mapa 1:100 tys.

134. Polska - mapa ogólnogospodarcza 1:650 000, [w:] Atlas Geograficzny Polski, PPWK, Warszawa, 1978, s. 34-35.

135. Główne problemy gospodarki przestrzennej w przemyśle na obszarze Polski w latach 1900-2000, [w:] System gospodarki przestrzennej, Biuletyn IGiPZ, Warszawa 1978, z. 26, s. 122-138.

136. Zmiany $w$ uprzemystowieniu Polski $w$ ukladzie nowych województw w latach 1939-1975, Biuletyn Informacyjny Zespołu Koordynacyjnego Problemu Międzyresortowego „Podstawy przestrzennego zagospodarowania kraju”, IGiPZ PAN, Warszawa 1979, 27, ss. 137 (wspólnie $\mathrm{z}$ W. Kaczorowskim).

137. The evolution of Polands industrial System 1946-1976, [w:] Observations of the Industrial System of Poland, Zeszyty Naukowe UJ, Prace Geograficzne, z. 48, PWN, Warszawa-Kraków 1979, s. 61-65.

138. Wpływ przemystu na rozwój miasta stolecznego na przykladzie Warszawy, [w:] Rola przemystu w rozwoju miast i miasto jako baza działalności przemystowej, Uniwersytet Łódzki, Łódź 1979, s. $21-35$.

139. Polskie miasta przemystowe - ich dotychczasowy rozwój i przyszłość, [w:] Strukturalne przeobrażenia wielkich miast przemysłowych, Uniwersytet Łódzki, Łódź 1979, s. 38-54.

140. Ośrodki przemystowe w 1970 r., [w:] J. Tazbir (red.), Zarys historii Polski, PIW, Warszawa 1979, mapa - wkładka $13 \mathrm{w}$ skali 1:4 000000.

141. Industrial development in the suburban zone of Warsaw, Geographica Slovenica, Ljubliana 1980, 11, s. 235-249.

142. Warsaw metropolita industrial system, [w:] Synopsis of papers Commission on Industrial Systems IGU, Tokyo 1980, s. 37-38.

143. Spatial problems of Polands postwar industrialization 1945-1975, Geographia Polonica, Warszawa 1980, 43, s. 199-212 (wspólnie z W. Kaczorowskim).

144. Niektóre aspekty industrializacji krajów Wschodniej Europy po 1945 r. (w języku japońskim), Chiri (Geografia), Tokio 1980, 25, 1, s. 89-101.

145. Żyrardów le plus important centre de l'industrie du lin en Pologne, Etudes Vauclusiennes, Avignon 1980, 23, s. 1-4.

146. Relacje demograficzne procesów industrializacji $i$ urbanizacji na ziemiach polskich, Roczniki Dziejów Społecznych i Gospodarczych, Warszawa 1980, 41, s. 280-282.

147. Polska - mapa ogólnogospodarcza 1:650 tys., [w:] Atlas Geograficzny Polski, PPWK, Warszawa 1980, wyd. II, s. 34-35.

148. Przemyst Warszawy wspótczesnej, [w:] Jesteśmy w Warszawie - miasto dawne i nowe, PIW, Warszawa 1981, t. 1, s. 422-444. 
149. Warszawski Okręg Przemystowy (hasło), [w:] Encyklopedia Historii Gospodarczej do 1945 r., Wiedza Powszechna, Warszawa 1981, s. 460-462.

150. Polska - mapa ogólnogospodarcza 1: 650 tys., [w:] Atlas Geograficzny Polski, PWK, Warszawa 1981, wyd. III, s. 34-45

151. Delimitacja Okręgów Przemystowych, Opracowania Regionalne GUS, Warszawa 1982, ss. 77 (wspólnie z S. Rolą Kunach i J. Wojtanem).

152. Miery po przemyszlennomu razwitju $w$ wostocznej Polsze, Izwiestia Sibirskogo Otdielenija Akademii Nauk SSSR, Seria Obszczestwiennych Nauk, Nowosybirsk 1982, s. 75-76.

153. Wspótczesne problemy przemystu w świetle przedkongresowego Sympozjum Komisji Systemów Przemystowych MUG w Tokio, [w:] Międzynarodowy Kongres Geograficzny w Tokio 1980, Przegląd Zagranicznej Literatury Geograficznej IGiPZ PAN, Warszawa 1982, z. 3-4, s. 82-102 (wspólnie z B. Kortusem).

154. Sympozjum Komisji Systemów Przemystowych MUG w Nyiregyhaza, Przegląd Geograficzny, 1982, t. LIV, z. 4, s. 612-613.

155. Regionalne zróżnicowanie procesu uprzemystowienia Polski 1945-1975, Studia KPZK PAN, Warszawa 1983, t. LXXVI, ss. 94 (wspólnie z W. Kaczorowskim).

156. Algierskie kontrasty, Mozaika algierska, Algier 1983, 2, s. 41-50

157. Polska-mapa ogólnogospodarcza 1: 650 tys., [w:] Atlas Geograficzny Polski, PPWK, Warszawa 1983, wyd. IV, s. 34-37.

158. Industrial Location and Planning (bibliografia międzynarodowa) VANCE Bibliographies, Monticello J.M. 1984, I-IV (wspólnie z E.W. Miller I R.M. Miller z Pensylvania State University)

159. The impact of industrialization on urbanization in Algieria, [w:] Abstracts of papers, 25 International Geographic Congress IGU, Paris 1984, 1, temat 8.25.

160. Polska-mapa ogólnogospodarcza 1: 650 tys., [w:] Atlas Geograficzny Polski, PPWK, Warszawa 1984, wyd. V, s. 34-37

161. New Technology In the industrial development of Algieria, Kathoslieke Universiteit of Nijmegen, 1985, ss. 16.

162. Zagadnienia delimitacji okręgów przemysłowych, [w:] Okręgi Przemysłowe w Polsce, Uniwersytet Łódzki, Łódź 1986, s. 1-10.

163. Polska-mapa ogólnogospodarcza 1: 650 000, [w:] Atlas Geograficzny Polski, PPWK, Warszawa 1986, wyd. VI, s. 34-37.

164. Industrial change in the peripheris of Poland, JGU Commission of Industrial Change, Madrit 1986, ss. 17.

165. Przestrzenne uprzemystowienie kraju w latach 1980-1985, Opracowanie analityczne GUS, Warszawa 1987 (wspólnie z L. Pakułą i M. Szybkowskim), ss. 105.

166. Sympozjum Komisji (C 10) Przemiany w przemyśle MUG, Chinchon 24-29 sierpnia 1986, [w:] Śródziemnomorska Konferencja Międzynarodowej Unii Geograficznej, Hiszpania 1986, PZGL IGiPZ PAN, 1987, z. 3-4, s. 61-64.

167. Polska - mapa ogólnogeograficzna 1:650 tys., [w:] Atlas Geograficzny Polski, PPWK, Warszawa-Wrocław 1987, wyd. VII, s. 34-37.

168. Research problems of the restructuring of industry In Polish Cities, [w:] Restructuring of the Industry in Towns, Uniwersytet Łódzki, Łódź 1988, s. 16-23.

169. The main trends of post-war spatial changes in Polish industry, [w:] Regional development in Japan and Poland, The Organizing Committee for Japan-Poland Economic Geography Seminar, Tokyo 1988, s. 143-158.

170. Rozwoj i tendencije lokalizacije industrije u metropolitanskim podruczjima Beograda $i$ Warszawe, Glasnik sprskog geograficko družstwa, Beograd 1988, nr 2 s. 27-42 (wspólnie z M. Grcičem).

171. Development of research studies In industrial geography, Geografski Pregled, Sarajewo 1988, nr 31/32, s. 16-23. 
172. Industrial Geography and Industrial Development Materialien und Kleine Schriffen, 120, Ruhr Uniwersität Bochum-Querenburg, 1988, ss. 70 (wspólnie z K. Hottesem i J. Singhem)

173. New technology in the industrial development of Algieria [w:] Materialien und Kleine Schrifen, Ruhr Uniwersität Bochum, Bochum-Querenburg, 1988, nr 120, s. 38-48.

174. Konferencja Komisji Przemian Przemystu MUG, Rabka 31.VIII.-6.IX.1987, Przegląd Geograficzny, 1988, t. LX, z. 3, s. 447-449 (wspólnie z B. Kortusem).

175. Polska - mapa ogólnogeograficzna 1:650 tys., [w:] Atlas Geograficzny Polski, PPWK, Warszawa-Wrocław 1988, wyd. VIII, s. 34-37.

176. Polska - mapa ogólnogeograficzna 1:650 tys., [w:] Atlas Geograficzny Polski, PPWK, Warszawa-Wrocław 1989, wyd. IX, s. 34-37, współautorstwo.

177. Polska - mapa ogólnogeograficzna 1:650 tys., [w:] Atlas Geograficzny Polski, PPWK, Warszawa-Wrocław 1989, wyd. X, s. 34-37.

178. Rozwój przemystu na Mazowszu, Biul. Inst. Gosp. Społ. SGH, Warszawa 1989/1990, nr 4, s. $70-156$.

179. Zagadnienia metodyczne badań nad ośrodkami przemysłowymi, Materiały i Sprawozdania, WSP Kraków 1990, nr 19, s. 146-150.

180. Structural changes in industry in the Bialystok Industrial District, [w:] The industry in textil and clothing agglomerations in Poland and in the World - problems of restructuring, Uniwersytet Łódzki, Łódź 1990, s. 55-63.

181. Some aspects of restructuring Warsaw's Industry, [w:] Regional Conference on Asian Pacific Countries, IGU Abstracts Bejing, 1990, nr 1, s. 7-14

182. Strukturelle und räumliche Wandlungen in der Industrie der Stadt Warschau, [w:] Evolution of population and economic activities in urban regions, Papers from the Polish-GDR Geographical Seminar, Szymbark, September 12-16 1988, IGiPZ PAN, Warszawa 1990, s. 82-97.

183. Liaisons internationals de l'industrie polonaise, [w:] Impact de mutations structurelles sur le development territorial en Europe, Conference Papers IGiPZ PAN, Warszawa 1991, nr 13, s. $117-126$.

184. Rozwój przemyslu Belgradu i Warszawy w latach 1945-1985, Industrial development of Belgrad and Warsaw 1945-1985, Sesja Naukowa IGiPZ PAN, Conference Papers, Warszawa 1991, nr 14, s. 125-138, (wspólnie z M. Grcičem).

185. Najnowsze przemiany geografii przemystu Polski, [w:] Polska - kraj na drodze przemian, Instytut Badań Edukacyjnych, Warszawa 1991, s. 53-59, mapki, tabele.

186. Osnownyje osobiennosti razwitija i rozmiešzčzenia promyšlennosti w staličnom regionie Polszy, Izdatielstvo Moskovskogo Universiteta, 1991, 13 s. + mapa (wspólnie z J. Iliničem).

187. Earthquake in E. Asnam Region (Algieria) on Ocotber 10.1980, [in:] W. Zelinsky, L. Kosinski, The emergency avcuation of cities, Rowman and Littlefield Publishers Inc., Savage, Maryland (USA), 1991, s. 74-78 (współautorstwo).

188. The latest changes in the geography of Polish Industry, [w:] Poland now, Leicester 1992, s. 53-64.

189. Przemiany strukturalne w przemyśle aglomeracji warszawskiej, Zeszyty IGiPZ PAN, Warszawa 1992, nr 11, ss. 58.

190. Industrial development of Warsaw 1945-1990, [w:] Liber amicorum Prof. dr Modest Goossens, Leuven 1992, s. 283-289.

191. Commission on Industrial Geography Poland, [w:] Notes from national study group, Bulletin of the IGU Commission on Industrial Change, Canberra 1992, nr 6, $6 \mathrm{~s}$.

192. Rozwój prywatyzacji przemystu w woj. stotecznym warszawskim na tle kraju, [w:] Geografia przemystu w warunkach nowego systemu gospodarowania, WSP, Kraków-Warszawa 1992, s. $108-123$.

193. Regional affects of privatization of Polish industry 1980-1990, Uniwersytet Łódzki, Łódź 1992, s. $32-44$. 
194. Międzynarodowa konferencja pod hastem ,,Wpływ czlowieka na środowisko”, Uusküla (Estonia), 19-25.08.1991, Przegląd Geograficzny, t. LXIV, z. 3-4, 1992, s. 418-420.

195. Międzynarodowa konferencja na temat „Procesy restrukturyzacji $w$ regionach przemystu węglowego i ciężkiego, Moskwa-Donieck, 26-31.08.1991, Przegląd Geograficzny, t. LXIV, z. 3-4, 1992, s. 421-422.

196. Spatial problems of industrial restructuring in Poland, [w:] Geographical issues of social and economic transformations of contemporary Japan and Poland, Conference papers IGiPZ PAN, nr 16, Warszawa 1992, s. 127-136.

197. Komisja/sekcja Geografii Przemystu (1979-1993), [w:] Polskie Towarzystwo Geograficzne w siedemdziesiata piqta rocznice działalności, Warszawa-Poznań 1993, s. 97-102.

198. Stopień prywatyzacji działalności gospodarczej w woj. warszawskim w 1991 r., [w:] 42 Zjazd PTG, 27-30.06.1993, Kielce, 1993, s. 152-153.

199. Change in the owner ship structure of the economic activity in Warsaw Urban Region, [w:] Urban and industrial change in the New economic order in the socialist countries, Proceedings of the conference Ocotober 11-15.1993, Łódź 1993, s. 33-41.

200. Prywatyzacja jako czynnik rozwoju regionów przygranicznych w Polsce, [w:] Czynniki i bariery rozwoju regionów przygranicznych, Kraków-Rzeszów-Warszawa 1993, s. 69-75.

201. Regionalne zróżnicowanie prywatyzacji przemystu, Przegląd Geograficzny, t. LXVI, 1993, nr 3-4, s. 255-277.

202. Wpływ wielkości zakładów i przedsiębiorstw przemysłowych na ich funkcjonowanie w okresie przejściowym do gospodarki rynkowej, [w:] Funkcjonowanie przedsiębiorstw przemysłowych w zmieniajacych się warunkach gospodarowania, WSP, Kraków-Warszawa 1994, s. 164-171.

203. Zacofanie i perspektywy rozwoju regionów przygranicznych wschodniej Polski, [w:] Ogólnopolski Zjazd PTG - referaty i postery, Lublin 1994, s. 174-175.

204. Przemyst (hasło), [w:] Encyklopedia Warszawy, Warszawa 1994, s. 704-707.

205. Zachodnia Dzielnica Przemystowa (hasło) [w:] Encyklopedia Warszawy, Warszawa 1994, s. 992.

206. Regionalny aspekt prywatyzacji gospodarki narodowej w Polsce w latach 1988-1991, [w:] Z. Zioło (red.), Zachowania przestrzenne przemystu w zmieniajacych się warunkach gospodarowania, Komisja Geografii i Przemysłu PTG, WSP, Kraków-Warszawa 1994, s. 22-38.

207. Ogólne tendencje transformacji regionalnych struktur działalności społeczno-gospodarczej w Polsce od roku 1989, [w:] J. Kotowski, Z. Zioło (red.), Problemy transformacji struktur regionalnych w procesie przechodzenia do gospodarki rynkowej, Wydawnictwo filii UMCS w Rzeszowie, Warszawa-Kraków-Rzeszów 1994, s. 91-100.

208. Structural transformations in main agglomerations of Poland since 1989 (synapsis of the paper), [w:] The third Japanese-Polish Geographical Seminar 30 X-4 XI 1994, Tadeshina and Nagoya, 1994.

209. Regional aspect of recent ownership transformation in the industry of Poland - paper presented to the Conference of the IGU Commision on the Organization of Industrial Space in Budapest, 15-21 August, 1994, ss. 12.

210. Structural transformation tendencies in the economy of the Warsaw agglomeration, [w:] Socioeconomic transformation of old urban and industrial agglomerations in Poland against the background of other East Central European countries, Uniwersytet Łódzki, Łódź 1995, s. $48-52$.

211. Industrie de l'aire metropolitaine de Varsovie Au cours de la transformation socioeconomic actuelle (streszczenie referatu), [w:] Seminaire Geographique polono-roumain Varsovie, le 12 juin 1995.

212. Structural transformations in main agglomerations of Poland since 1989, [w:] The roles of metropolita urban areas in the high-consumption society and other geographical issues of Contemporary Japan and Poland, Nagoya 1995, s. 279-296. 
213. Development of the industrial areas in Warsaw and trends in their restrucutin, [in:] Restructuring of Derelict Industrial Areas, European Academy of the Urban Environment, Berlin 1996, s. $110-114$.

214. Restrukturyzacja gospodarki Warszawy i problem zagospodarowania terenów poprzemysłowych, [w:] Polska w Europie Battyckiej, 45 Zjazd PTG, Słupsk 1996, s. 181-182.

215. Problems of restructuring and redevelopment of the derelict industrial areas in Warsaw, Revue Belge de Geographie, 1996, nr 120, s. 79-81.

216. Transformacja strukturalna w przemyśle Warszawy, [w:] Z. Zioło (red.), Wpływ procesów transformacji gospodarki narodowej na funkcjonowanie jednostek gospodarczych i układów przestrzennych, PTG, Kraków 1996, s. 12-17.

217. Shigeru Yamamoto członkiem honorowym Polskiego Towarzystwa Geograficznego, Czasopismo Geograficzne, z. 2, 1996, s. 271-272.

218. Rozmieszczenie przemystu wedhug miejscowości, plansza 93.3, Atlas Rzeczypospolitej Polskiej, cz. IV Gospodarka, Warszawa 1996.

219. Przemyst chemiczny, plansza 93.5, Atlas Rzeczypospolitej Polskiej, cz. IV Gospodarka, Warszawa 1996 (wspólnie z W. Bąk),

220. Przemyst mineralny, plansza 93.6, Atlas Rzeczypospolitej Polskiej, cz. IV Gospodarka, Warszawa 1996 (wspólnie z H. Piotrowską).

221. Przemyst drzewny i papierniczy, plansza 93.7, Atlas Rzeczypospolitej Polskiej, cz. IV Gospodarka, Warszawa 1996 (wspólnie z W. Bąk).

222. Przemyst spożywczy, plansza 93.8, Atlas Rzeczypospolitej Polskiej, cz. IV Gospodarka, Warszawa 1996 (wspólnie z W. Bąk i H. Piotrowską).

223. Przemyst lekki, plansza 93.9, Atlas Rzeczypospolitej Polskiej, cz. IV Gospodarka, Warszawa 1996 (wspólnie z H. Piotrowską).

224. Przemyst strefy podmiejskiej Warszawy w okresie transformacji, [w:] Przemiany struktury przestrzennej obszarów wiejskich w strefie podmiejskiej stolic Polski, Conference Papers IGiPZ PAN, nr 25, Warszawa 1996, s. 103-116.

225. Ważniejsze ośrodki przemystowe 1939, 1945, 1980, 1985, plansza 93.1, Atlas Rzeczypospolitej Polskiej, cz. IV Gospodarka, Warszawa 1996 (4 mapy w skali 1:3 mln).

226. Przemyst maszynowo-metalowy, plansza 93.4, Atlas Rzeczypospolitej Polskiej, cz. IV Gospodarka, Warszawa 1996 (mapa w skali 1:1,5 mln).

227. Stanisław Leszczycki jako uczony, organizator nauki, pedagog i redaktor, Czasopismo Geograficzne, 1997, t. LXVIII, nr 3-4, s. 271-281.

228. Rozwój geografii przemystu i jej problematyki badawczej, [w:] Geografia-człowiek-gospodarka, IG UJ, Kraków 1997, s. 115-123.

229. Ogólne tendencje restrukturyzacji przemystu Warszawy w latach 1989-1997, [w:] Przyrodnicze i społeczne walory Mazowsza w dobie restrukturyzacji, 46 Zjazd PTG, Rynia 18-21 IX 1997, PTG, Oddział Warszawski, Warszawa-Rynia 1997, s. 230-233.

230. Rozwój funkcji przemystowej Warszawy w latach o międzywojennych, [w:] Warszawa w dziejach Polski, PWN, Warszawa 1997, s. 191-192.

231. Deindustrialization of Warsaw and redevelopment problems of derelict industrial sreas, [w:] Prozesse und Perspektiven der Stadtentwicklung in Ostmitteleuropa, Münchener Geographische Hefte 1997, nr 76, s. 125-129.

232. Structural transformation tendencies in the Economy of Warsaw Agglomeration, [w:] Occasional Paper of Department of Geography, Saitama University (Japan), nr 12, s. 13-16.

233. Development of the Industrial Areas of Warsaw and the Trends in their Restructuring, [w:] Occasional Paper of Department of Geography, Saitama University (Japan), 1997, nr 17, s. 17-22.

234. Mutations structurelles indusrielles dans la region metropolitaine de Varsovie, [w:] Nouveaux espaces et systčmes urbaines, Livre Jubilaire en hommage au Professeur Bernard Dézert, Sedes, Paris 1998, s. 335-356. 
235. Dorobek polskiej geografii przemysłu w badaniach ośrodków akademickich, S. Misztal, Z. Zioło (red.), Wyd. Krakowskiego Oddziału PAN, Warszawa-Kraków 1998, ss. 268.

236. Wprowadzenie, [w:] S. Misztal, Z. Zioło (red.), Dorobek polskiej geografii przemystu w badaniach ośrodków akademickich, Wyd. Krakowskiego Oddziału PAN, Warszawa-Kraków 1998, s. 9-16 (wspólnie z Z. Zioło).

237. Działalność Komisji Geografii Przemystu 1979-1996, [w:] S. Misztal, Z. Zioło (red ), Dorobek polskiej geografii przemystu w badaniach ośrodków akademickich, Wyd. Krakowskiego Oddziału PAN, Warszawa-Kraków 1998, s. 17-26.

238. Dorobek warszawskiego ośrodka naukowego w dziedzinie geografii przemystu, [w:] S. Misztal, Z. Zioło (red), Dorobek polskiej geografii przemyslu w badaniach ośrodków akademickich, Wyd. Krakowskiego Oddziału PAN, Warszawa-Kraków 1998, s. 27-95.

239. Przeksztatcenia struktury przemystu Warszawy, Atlas Warszawy, z. 6, Warszawa 1998, ss. 193 +19 barwnych map.

240. Kierunki zmian w strukturze funkcjonalnej i przestrzennej miast Unii Europejskiej, [w:] J.K. Chmielewski (red.), Przestrzeń Europy, TUP Oddział Warszawski, 1999, s. 14-77.

241. Współczesne problemy przemystu Warszawy, [w:] Warszawa 2000, Wyd. Adam, Warszawa 1999, s. $83-88$.

242. Development of industrial output in Warsaw, [in:] The Great Book of Warsaw, Wyd. Syrenka, Warszawa 2000, s. 448-467.

243. Profersor Toshio Nohara członkiem honorowym Polskiego Towarzystwa Geograficznego, Czasopismo Geograficzne, 2000, 71, s. 241-242.

244. Regionalne efekty procesu prywatyzacji przemystu w Polsce w latach 1989-1995, [w:] Z. Zioło (red.), Problemy transformacji struktur przemystowych $w$ procesie przechodzenia do gospodarki rynkowej, Wyd. Naukowe AP, Warszawa-Kraków 2000, s. 23-33.

245. Przemyst Warszawy w końcu XIX i XX wieku, Kronika Warszawy, 2000, z. 3-4, s. 21-31.

246. Misztal Stanisław (biogram), [w:] Wspótcześni uczeni polscy - Słownik biograficzny, Ośrodek Przetwarzania Informacji, Warszawa 2000, t. III (M-R), 204 s.

247. Jan Gruszka (1907-1980) - w dwudziesta rocznicę śmierci, Czasopismo Geograficzne, 2001, 72, z. 1 , s. 120-122.

248. Zarys biografii (Jana Gruszki), [w:] Jan Gruszka „Bartos”. Życie i działalność, Artykuły, wspomnienia, dokumenty, Muzeum Historii Polskiego Ruchu Ludowego, Warszawa, 2001, s. 13-34.

249. Leszczycki Stanistaw (biogram), [w:] Polska Geografia Przemystu i Budownictwa w XX wie$k u$ - Sylwetki, Wyd. UŁ i Komisja Geografii Przemysłu PTG, Łódź-Warszawa-Kraków 2001, s. 62-66 (współautorstwo).

250. Misztal Stanistaw (biogram), [w:] Polska Geografia Przemystu i Budownictwa w XX wieku - Sylwetki, Wyd. UŁ i Komisja Geografii Przemysłu PTG, Łódź-Warszawa-Kraków 2001, s. 87-91 (współautorstwo).

251. Nowe tendencje w rozwoju przemystu Warszawy, [w:] J. Rajman (red.), Polska - Europa, gospodarka, przemyst, Wyd. Nauk. Akademii Pedagogicznej, Kraków 2001, s. 139-153.

252. Tajne nauczanie w zakresie szkoty średniej ogólnoksztatcacej na wsi iłżeckiej w czasie II wojny światowej, Zeszyty Kombatanckie AK „Jodła”, nr 33, Warszawa, 2002, s. 45-57.

253. List do Redakcji Życia Powiśla w sprawie projektowanej monografii Ziemi Lipskiej, Życie Powiśla, 2002, nr 3(8), s. 98.

254. Odpowiedź na list podpisany przez 6 czytelników Życia Powiśla dotyczqcy niektórych stwierdzeń zamieszczonych w zarysie biografii Jana Gruszki, Życie Powiśla, 2002, nr 4(9), s. 94.

255. Transformacja własnościowa działalności przemysłowej $w$ Polsce wedlug województw, [w:] Z. Zioło, Z. Makieła (red.), Kształtowanie struktur przemysłowych, Komisja Geografii Przemysłu PTG w Warszawie, IG AP w Krakowie, Warszawa-Kraków 2003, s. 9-30.

256. Uwagi dotyczqce treści niektórych tekstów zamieszczonych w Życiu Powiśla, numery 1-8, Życie Powiśla, 2003, nr 1(10), s. 89. 
257. Wspomnienie prałata Tadeusza Stańkowskiego (1927-2003), Życie Powiśla, 2004, nr 3, s. 63 (współautorstwo).

258. Śp. Ks. Prałat mgr Tadeusz Stańkowski (1927-2003), Kronika Diecezji Radomskiej, 2004, r. 13, nr 2(50), s. 229-231.

259. Kilka uwag na temat liczby i składu etnicznego mieszkańców Jedwabnego w latach międzywojennych, [w:] R. Jaworek, Wypędzeni, Wyd. Antyk, Warszawa 2004, s. 118-134.

260. Ks. Dr Stanisław Gtabiński (1892-1965) - wspomnienie rodzinne, Kronika Diecezji Radomskiej, r. 15, nr 3(59), s. 409-417.

261. Śp. Ksiqdz doctor Stanisław Gtabiński (1892-1965) wspomnienie rodzinne, Życie Powiśla, 2006, nr 2, s. 10-11.

262. Wytwórczość przemysłowa (w ziemi lipskiej) do roku 1945, [w:] Cz. Barański (red.), Ziemia Lip$s k a$, Wyd. NPBLES-not, Warszawa 2006, t. I, s. 145-148.

263. Tajne nauczanie na przykładzie Dlugowoli, Józefowa, i Władysławowa [w:] Cz. Barański (red.), Ziemia Lipska, Wyd. NOBLES-not, Warszawa 2006, t. I, s. 191-194.

264. Jan Misztal (1892-1958) (biogram), [w:] Cz. Barański (red.), Ziemia Lipska, Wyd. NOBLES-not, Warszawa 2006, t. I, 277 s.

265. Stanisław Misztal (biogram), [w:] Cz. Barański (red.), Ziemia Lipska, Wyd. NOBLES-not, Warszawa 2006, t. I, s. 258-259.

266. Ks. Dr Stanisław Gtabiński (1892-1965), Białobrzeskie Towarzystwo Kulturalne - Rocznik, Białobrzegi 2005/2009, s. 17-22.

267. Straty osobowe rodziny Kwapińskich wywodzacych się z Osówki Nowej podczas I wojny światowej, Życie Powiśla, 2009, z. 2(35), s. 24-27 (wspólnie z W. Kwapińskim).

268. Aleksy Owczarek (1910-1988) (biogram), Życie Powiśla, 2009, z. 2(35), 20 s. (wspólnie z M. Kowalska).

269. Józef Gtabiński (1898-1970) (biogram), Życie Powiśla (w druku).

270. Marian Dębiec (1910-1992) (biogram), Życie Powiśla (w druku).

Opracowała

Wioletta Kilar 